\title{
Psychische klachten tijdens en na COVID-19
}

\author{
André Weel
}

Illegems J, Eede F van den, Nys A de et al. Mentaal welzijn na hospitalisatie voor COVID-19. Tijdschrift voor Geneeskunde 2020;76(20):1008-1018. doi. org/10.47671/TVG.76.20.1389
Op basis van hun ervaringen met een geïntegreerde intramurale aanpak bij gehospitaliseerde COVID-19-patiënten, en ondersteund door de beschikbare literatuur en de bestaande richtlijnen voor de geestelijke gezondheidszorg, onderstrepen de auteurs het belang van aandacht en begeleiding voor mentaal welzijn in de nazorg voor deze patiënten. Voorts formuleren zij aanbevelingen voor de eerste lijn.

Dit is een bijzonder artikel in het Vlaamse Tijdschrift voor Geneeskunde. Het is een case study van een samenwerking tussen klinische afdelingen van een academisch ziekenhuis met psychologen en psychiaters, om de veel voorkomende psychische problemen bij COVID-19-patiënten aan te pakken, en tegelijkertijd een narratief review van de literatuur over de interventies bij deze problemen.

De situatie is complex. COVID-19-patienten worden blootgesteld aan somatische, psychische en sociale stressoren. Denk daarbij aan de berichten in de media, de quarantainemaatregelen, de maatschappelijke impact, alsook aan mogelijke traumatische ervaringen door acute ademhalingsproblemen, en een langdurig herstelproces met beperkingen in het functioneren. Als gevolgen van deze stressoren ziet men psychische stoornissen: angst, depressie, posttraumatische stress, slapeloosheid, rouw en neurocognitieve symptomen. In het Universitaire Ziekenhuis van Antwerpen (UZA) hebben de diensten klinische psychologie en psychiatrie samen met een aantal klinische afdelingen een geïntegreerd psychologisch en -psychiatrisch zorgprogramma ontwikkeld en uitgevoerd.

De conclusie is dat psychische zorg een essentieel onderdeel moet zijn van de klinische zorg en de ambulante nazorg. De belangrijkste aanbeveling van de auteurs is de ondersteuning na hospitalisatie in de vorm van psycho-educatie en begeleiding, en het leren toepassen van copingvaardigheden bij langdurige klachten.

De focus van COVID-19-patiënten ligt aanvankelijk vooral op fysiek herstel. Dat verklaart waarom mentale symptomen zich pas na verloop van tijd ontwikkelen. Het is dus belangrijk het mentale welzijn van patiënten en hun psychosociale context actief te volgen. Als screenings- en monitoringsinstrumenten bevelen de auteurs de Brief Symptom Inventory (BSI), de Vierdimensionele Klachtenlijst (4DKL) of de WHO (vijf) welzijnsindex (WHO-5) aan. De nadruk ligt daarbij op vroege detectie en brede, laagdrempelige ondersteuning.

Op geleide van het herstel wordt vanuit de klinische ervaring bij patiënten met postinfectieuze vermoeidheid een arbeidsongeschiktheid van meerdere weken aangehouden. Tegelijk wordt een stapsgewijze werkhervatting aanbevolen, waarbij voldoende hersteltijd voor de patiënt gewaarborgd is. Hoe kan de dagplanning van de patiënt worden aangepast aan aan diens draagkracht? Korte taken, liggende en zittende rust, ontspanning en beweging worden over de dag afgewisseld, waarbij de regel van 20 minuten houvast kan bieden. Die houdt in dat activiteiten na 20 minuten worden onderbroken, gevolgd door een korte pauze of een taak met een andere soort belasting (fysiek of mentaal, zittend of staand).

Patiënten die behandeld zijn op de IC kunnen maanden na de hospitalisatie nog een full-blown PTSS ontwikkelen. $\mathrm{Na}$ een verblijf op de IC ontbreken er vaak herinneringen. Om het gat in het geheugen te vullen, kan praten met hulpverleners en naasten, of een bezoek aan de IC waar de patiënt heeft gelegen van nut zijn. Bij PTSS is traumatherapie door een psychotherapeut aangewezen, zonodig in combinatie met een antidepressivum. Veel patiënten hebben last van aanhoudende fysieke, mentale en cognitieve symptomen, beschreven als het post-intensive-care-syndroom. Als psycho-educatie is een patiëntenbrochure Mentaal herstellen na COVID-19 beschikbaar. Brochure A5 - 8 pagina's (uza.be) 